\title{
Fractioning and chemical characterization of barks of Betula pendula and Eucalyptus globulus
}

\author{
Isabel Miranda, Jorge Gominho*, Inês Mirra, Helena Pereira \\ Centro de Estudos Florestais, Instituto Superior de Agronomia, Universidade Técnica de Lisboa, Tapada da Ajuda, 1349-017 Lisboa, Portugal
}

\section{A R T I C L E I N F O}

\section{Article history:}

Received 17 February 2012

Received in revised form 3 April 2012

Accepted 14 April 2012

\section{Keywords:}

Betula pendula Roth.

Eucalyptus globulus Labill.

Bark

Particle size

Chemical composition

\begin{abstract}
A B S T R A C T
The composition of birch (Betula pendula Roth.) and eucalypt (Eucalyptus globulus Labill.) barks was studied after grinding and fractioning into different particles sizes.

There was a significant difference in the fractionation of both barks in relation to the yield of fines (5.9\% and $28.3 \%$ of particles under 0.450 for birch and eucalypt, respectively) and of coarser particles over $2 \mathrm{~mm}$ (70.7\% and $41.4 \%$ ).

The chemical composition of birch and eucalypt barks, as a mass weighed average of all granulometric fractions was, respectively: ash $2.9 \%$ and $12.1 \%$; total extractives $17.6 \%$ and $6.5 \%$ (hydrophilic extractives were dominant), lignin $27.9 \%$ and $28.8 \%$ and holocellulose $49.8 \%$ and $62.6 \%$. Birch bark contained a considerable amount of suberin (5.9\%) whereas eucalypt bark contained a very small amount $(<1 \%)$. The carbohydrate composition differed between birch and eucalypt barks, i.e., respectively, glucose $47.0 \%$ and $68.4 \%$, and xylose $33.8 \%$ and $23.2 \%$ of total neutral monosaccharides.

Ash elemental composition was different in both species. Birch bark contained in relation to eucalypt bark, in the $0.250-0.450 \mathrm{~mm}$ fraction, more $\mathrm{N}(0.69 \%$ vs. $0.26 \%)$ and $\mathrm{P}(0.075 \%$ vs. $0.001 \%)$, and less Ca ( $0.39 \%$ vs. $0.62 \%), \mathrm{K}(0.24 \%$ vs. $0.31 \%)$ and $\mathrm{Mg}(0.07 \%$ vs. $0.15 \%)$. High concentration of $\mathrm{Zn}$ was found in birch bark ( $217 \mathrm{mg} / \mathrm{kg}$ vs. $11 \mathrm{mg} / \mathrm{kg}$ in eucalypt bark).

After grinding and granulometric separation, extractives were present preferentially in the finest fraction with an enrichment in dichloromethane and ethanol solubles especially in the case of birch bark. Eucalypt bark had a high content of cellulose and hemicelluloses especially in the coarser fraction. The fibrous character of this fraction shows its potential as a fiber source.
\end{abstract}

(c) 2012 Elsevier B.V. All rights reserved.

\section{Introduction}

Bark represents a substantial proportion of the aboveground total biomass of trees. During industrial processing for timber or for pulping, bark is removed from the logs and constitutes an important mill residual material that is usually burnt for energy production. In addition to being considered a valuable solid biofuel, bark is also scrutinized for more added-value products that will consider potential specific chemical composition or properties (Demirbas, 2010).

Bark valorization, namely if envisaged within a biorefinery platform, therefore requires a careful examination of composition and processing characteristics. Barks are usually rich in extractives, including organic solvent and water solubles, and in polyphenolics, and they also contain a high amount of inorganic material (Fengel and Wegener, 1984; Pereira et al., 2003). Structurally barks

\footnotetext{
* Corresponding author.

E-mail address: jgominho@isa.utl.pt (J. Gominho).
}

are complex tissues and their sampling, characterization and processing have difficulties that are not found, e.g. in wood processing.

Hardwood species are presently the most important source of wood for pulp production (Patt et al., 2006). White birch (Betula pendula) is the dominant pulpwood species in Northern European countries (especially in Finland and Russia) and eucalypts (mainly Eucalyptus globulus) are dominant in Portugal and Spain, in Southern Europe. The pulpwood consumption in Europe in 2010 of birch and eucalypt was, respectively, 18425 million $\mathrm{m}^{3}$ and 13708 millions $\mathrm{m}^{3}$, corresponding to $12.5 \%$ and $9.3 \%$ of the total pulpwood consumption (CEPI, 2010).

In both cases considerable amounts of bark are made available from log debarking, and are separated in the mill as a residual product and used as fuel.

In E. globulus trees at the age used for pulping (9-13 years in temperate climates) bark has a thickness in the range of 3-16 mm and corresponds to $7-20 \%$ of o.d. mass of the stem depending on site and genetics (as compiled in Pereira et al., 2010).

There are few studies on B. pendula bark content. Jensen (1948) reported $3.4 \%$ outer bark in birch logs. Bhat (1982) referred that bark thickness is strongly associated with stem diameter and reported 
a mean value of $16.6 \mathrm{~mm}$ for the double bark thickness of trees aged 65-95 years. Repola (2008) reported a double bark thickness at breast height between 2.5 and $38.7 \mathrm{~cm}$ in trees within an age range of 7 and 132 years. For young trees with 1-16 years of age and $0.3-24.0 \mathrm{~cm}$ stem diameter, Trockenbrodt (1991) reported bark thickness values between 7.1 and $26.1 \mathrm{~mm}$.

Some studies have characterized eucalypt bark anatomically (Quilhó et al., 1999, 2000) and chemically (Sakai, 2001; Bargatto, 2010) as well as birch bark (Bhat, 1982; Trockenbrodt, 1991; Harkin and Rowe, 1971). However little is known on their fractioning behavior and on the chemical characteristics of different fractions. The use of fractioning is usually involved in biomass processing and may be used for selective enrichment of specific components by taking advantage of the biomass chemical and structural heterogeneity (Miranda et al., 2012; Silva et al., 2011). However, this is species specific and depends on the specific bark characteristics, as recently shown for Picea abies, Pinus sylvestris and Quercus cerris (Miranda et al., 2012; Sen et al., 2010).

This paper studies the chemical composition of the barks of these two important European hardwoods, silver birch (B. pendula) and Tasmanian blue gum (E. globulus), obtained as residual by-products of commercial debarking in pulp mills, after fractionation into different particle sizes. Summative chemical analysis and inorganic composition were determined for each granulometric fraction, as well as bulk density. The objective is to analyze the potential of triturating and particle fractioning as a biomass pretreatment step for a selective component enrichment within a bark valorization chain for energy, composite materials and chemicals.

\section{Materials and methods}

\subsection{Sampling}

Barks from birch (B. pendula Roth) and eucalypt (E. globulus Labill.) were obtained by industrial stem debarking in pulp mills, and were provided by Södra (Sweden) and Celbi (Portugal), respectively. The bulk bark samples were air-dried at ambient conditions and any visible wood chips were removed.

\subsection{Fractioning}

The barks were fractionated using a knife mill (Retsch SM 2000) with an output sieve of $10 \mathrm{~mm} \times 10 \mathrm{~mm}$ and screened using a vibratory sieving apparatus (Retsch AS 200 basic). The following sieve mesh sizes were used: $80(0.180 \mathrm{~mm}), 60(0.250 \mathrm{~mm}), 40$ $(0.450 \mathrm{~mm}), 20(0.850 \mathrm{~m}), 15(1.0 \mathrm{~mm})$ and $10(2.0 \mathrm{~mm})$. The mass of the fraction retained on each sieve was weighed and the corresponding seven mass fractions yields were determined.

\subsection{Bulk density}

The bulk density of the granulated samples was determined for each sieve fraction using a cylindrical container $(29.8 \mathrm{~mm}$ height $\times 28.1 \mathrm{~mm}$ diameter) as the ratio of the mass sample in the container to the volume of the container. The determination was made in triplicate samples.

\subsection{Microscopic observations}

The different granulometric fractions of the bark samples were observed microscopically after cell dissociation by maceration in a 1:1 glacial acetic acid:hydrogen peroxide solution, and staining with astra blue.

\subsection{Chemical characterization}

Chemical summative analysis included determination of ash, extractives soluble in dichloromethane, methanol, ethanol and water, suberin, Klason and acid soluble lignin, and holocellulose, as well as the monomeric composition of polysaccharides.

The granulometric fractions with particle size over 40 mesh were carefully ground prior to chemical analysis in order to obtain particles that passed through the 40 mesh sieve.

The unextracted bark samples were used to determine $1 \% \mathrm{NaOH}$ solubles.

Ash content was determined according to TAPPI Standard T 15 os-58 using $2.0 \mathrm{~g}$ samples as the residue of overnight incineration at $450-500^{\circ} \mathrm{C}$.

The alkaline lixiviation with $1 \% \mathrm{NaOH}$ was carried out in a stirred glass reactor with reflux using $1.0 \mathrm{~g}$ of material with a $1: 50$ solid:liquid ratio, at $100^{\circ} \mathrm{C}$ during $1 \mathrm{~h}$.

Solvent extraction was performed in a Soxtec extractor successively with dichloromethane, methanol, ethanol and water during $1.5 \mathrm{~h}$ with each solvent, and the extractives solubilized by each solvent were determined using the mass difference from the mass of the solid residue after drying at $105^{\circ} \mathrm{C}$ and reported as a percentage of the original samples.

Suberin content was determined on $1.5 \mathrm{~g}$ of extractive-free material by refluxing with $100 \mathrm{ml}$ of a $3 \% \mathrm{NaOCH}_{3}$ solution in $\mathrm{CH}_{3} \mathrm{OH}$ during $3 \mathrm{~h}$ (Pereira, 1988a). The sample was filtrated, washed with methanol, again refluxed with $100 \mathrm{ml} \mathrm{CH}_{3} \mathrm{OH}$ for $15 \mathrm{~min}$ and filtrated. The combined filtrates were acidified to $\mathrm{pH}$ 6 with $2 \mathrm{M} \mathrm{H}_{2} \mathrm{SO}_{4}$ and evaporated to dryness. The residue was suspended in $50 \mathrm{ml}$ water and the alcoholysis products recovered with dichloromethane in three successive extractions, each with $50 \mathrm{ml}$ dichloromethane. The combined extracts were dried over anhydrous $\mathrm{Na}_{2} \mathrm{SO}_{4}$ and evaporated to dryness. The suberin extracts, that include the fatty acid and fatty alcohol monomers of suberin, were quantified gravimetrically, and the results expressed in percent of the initial dry mass.

Klason and acid-soluble lignin, and carbohydrates contents were determined on $0.35 \mathrm{~g}$ of extracted and desuberinized samples. Sulfuric acid $(72 \%, 3.0 \mathrm{ml})$ was added to the sample and the mixture placed in a water bath at $30^{\circ} \mathrm{C}$ for $1 \mathrm{~h}$ after which the sample was diluted to a concentration of $3 \% \mathrm{H}_{2} \mathrm{SO}_{4}$ and hydrolyzed for $1 \mathrm{~h}$ at $120^{\circ} \mathrm{C}$. The sample was vacuum-filtered through a crucible and washed with boiling purified water. Klason lignin was determined as the mass of the solid residue after drying at $105^{\circ} \mathrm{C}$ and acid-soluble lignin was determined on the filtrate by measuring the absorbance at $206 \mathrm{~nm}$ using a UV/VIS spectrophotometer. Klason lignin and acid-soluble lignin were reported as percentage of the original sample and combined to give the total lignin content.

The polysaccharides were calculated based on the amount of the neutral sugar monomers released by total hydrolysis, after derivatization as alditol acetates and separation by gas chromatography with a method adapted from Tappi $249 \mathrm{~cm}-00$. The hydrolyzed carbohydrates were derivatized as alditol acetates and separated by GC (HP 5890A gas chromatograph) equipped with a FID detector, using helium as carrier gas ( $1 \mathrm{ml} / \mathrm{min})$ and a fused silica capillary column $\mathrm{S} 2330(30 \mathrm{~m} \times 0.32 \mathrm{~mm}$ i.d. $\times 0.20 \mu \mathrm{m}$ film thickness $)$. The column program temperature was $225-250^{\circ} \mathrm{C}$, with $5^{\circ} \mathrm{C} / \mathrm{min}$ heating gradient, and the temperature of injector and detector was $250^{\circ} \mathrm{C}$. For quantitative analysis the GC was calibrated with pure reference compounds and inositol was used as an internal standard in each run.

The holocellulose content was determined on the extractivefree samples by the chlorite method (Rowell, 2005): $1 \mathrm{~g}$ of sample was placed in an Erlenmeyer flask $(300 \mathrm{ml})$ and $32 \mathrm{ml}$ of distilled water was added. While slowly shaking, $0.750 \mathrm{~g}$ of $\mathrm{NaClO}_{2}$ and $0.3 \mathrm{ml}$ of acetic acid were added and the flask was covered with 
Table 1

Mass yields (\% of total dry mass) of the different granulometric fractions after milling of barks.

\begin{tabular}{lcc}
\hline Granulometric fraction, $\mathrm{mm}$ & \multicolumn{2}{c}{ Mass yield, \% } \\
\cline { 2 - 3 } & Birch & Eucalypt \\
\hline$<0.180$ & 2.3 & 17.8 \\
$0.180-0.250$ & 1.4 & 4.3 \\
$0.250-0.450$ & 2.2 & 6.2 \\
$0.450-0.850$ & 6.2 & 16.9 \\
$0.850-2.00$ & 17.1 & 13.6 \\
$>2.00$ & 70.7 & 41.4 \\
\hline
\end{tabular}

glass and boiled at $70-80^{\circ} \mathrm{C}$ for $60 \mathrm{~min}$. Again, $0.750 \mathrm{~g}$ of $\mathrm{NaClO}_{2}$ and $0.3 \mathrm{ml}$ of acetic acid were added and boiled 3 times. After cooling, the sample was filtered using a filter flask and washed with cold water and acetone $50 \%$ until free of acid. The insoluble portion was dried at $105^{\circ} \mathrm{C}$ for $4 \mathrm{~h}$, cooled in a desiccator and weighed until constant weight. The ash content of the obtained holocellulose was determined by incineration and the ash-free holocellulose content was calculated as percent of dry mass of the initial sample.

\subsection{Ash composition}

Nitrogen was determined by the Kjeldahl method (Jackson, 1958) in a Tecator equipment (Herdon, VA, USA). After a hydrochloric digestion of the ash (Marti and Muñoz, 1957), phosphorus was determined by molecular absorption spectrometry in a Hitachi U-2000 VIS/UV equipment, and all the other minerals were determined by atomic absorption spectrophotometer in a Pye Unicam SP-9 apparatus (Cambridge, UK) equipped with a graphite furnace GF95.

\section{Results and discussion}

\subsection{Bark fractioning}

The barks of birch (B. pendula Roth.) and eucalypt (E. globulus Labill.) were milled and the mass yields obtained for the different granulometric fractions are summarized in Table 1.

There was a significant difference in the fractionation of both barks. For birch bark the yield of fines was low, i.e. only $5.9 \%$ were particles under $0.450 \mathrm{~mm}$, and the major fraction corresponded to the largest particles, i.e. $70.7 \%$ of particles over $2 \mathrm{~mm}$. This grinding behavior with little formation of fines was also found for conifer barks of Pinus pinaster (Vázquez et al., 1987), P. sylvestris and $P$. abies (Miranda et al., 2012).

On the contrary, in the case of eucalypt bark a significant amount of fines was obtained with $17.8 \%$ of particles under $0.180 \mathrm{~mm}$ and the fractions with the larger particles showed comparatively lower yields (e.g. $41 \%$ for particles over $2 \mathrm{~mm}$ ).

These results show that the milling process applies differently to different barks and the bark structural features influence the grinding behavior. Barks are made up of different tissues - phloem, periderm and rhytidome - in varying extent and cellular characteristics.

In the case of eucalypt bark, there is no rhytidome, since older periderms are shedded out by the tree and only a thin periderm covers the phloem (Quilhó et al., 2000). The phloem is rather uniform and is characterized by tangential layers of axial parenchyma cells that are interspersed by regions of fibers, representing, respectively, $50 \%$ and $28 \%$ of the total cross-sectional area (Quilhó et al., 1999, 2000). It is therefore understandable that fracture occurs preferentially by the fragile and thin walled parenchyma regions, leaving the fibrous bundles in the coarser fractions. This could be tracked macroscopically since the $>2 \mathrm{~mm}$ fraction had a clear a
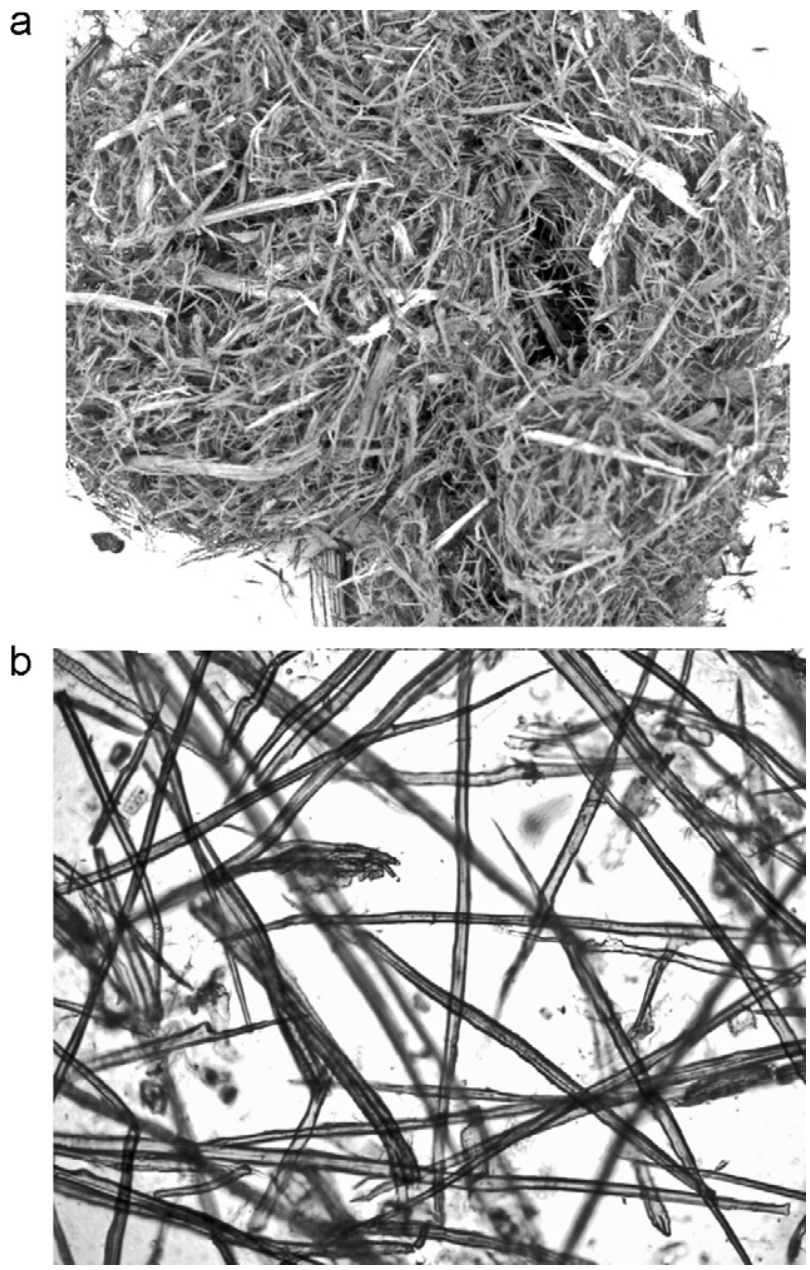

Fig. 1. Eucalypt (Eucalyptus globulus Labill.) bark. (a) Granulometric fraction with $>2 \mathrm{~mm}$ particles, observed under the magnifying glass; (b) microscopic observations of dissociated cells obtained from the 1 to $2 \mathrm{~mm}$ granulometric fraction.

fibrous aspect (Fig. 1a) which was further observed microscopically by analyzing the cell types after dissociation (Fig. 1b).

Birch bark is markedly different in structure. It is composed of two distinct zones, the phloem and an important outer bark (rhytidome) consisting of numerous tightly packed periderms that include phellem layers of thick and thin-walled cork cells (Bhat, 1982). The phloem has a great proportion of scelenchyma and the proportion of sclereids predominates over that of fibers. In consequence the coarser fraction of birch differed macroscopically from that of eucalypt bark showing an aspect of irregularly more or less cubic particles of phloem and of flakes shaped particles from the rhytidome (Fig. 2a). Microscopically, aggregates of sclerified cells and of the phellem tissue could be observed (Fig. 2b).

\subsection{Bulk density}

Table 2 gives the bulk density of the different bark granulometric fractions. Both barks differed significantly in density, with mean values of $277 \mathrm{~kg} / \mathrm{m}^{3}$ and $169 \mathrm{~kg} / \mathrm{m}^{3}$ for birch and eucalypt, respectively. In the case of birch bark there is a clear trend of increasing bulk density with the decrease of particle dimension in agreement with the overall idea that small particles may be better compacted than larger particles.

The eucalypt bark granulates did not show a clear trend of density variation with particle size and the differences in density 


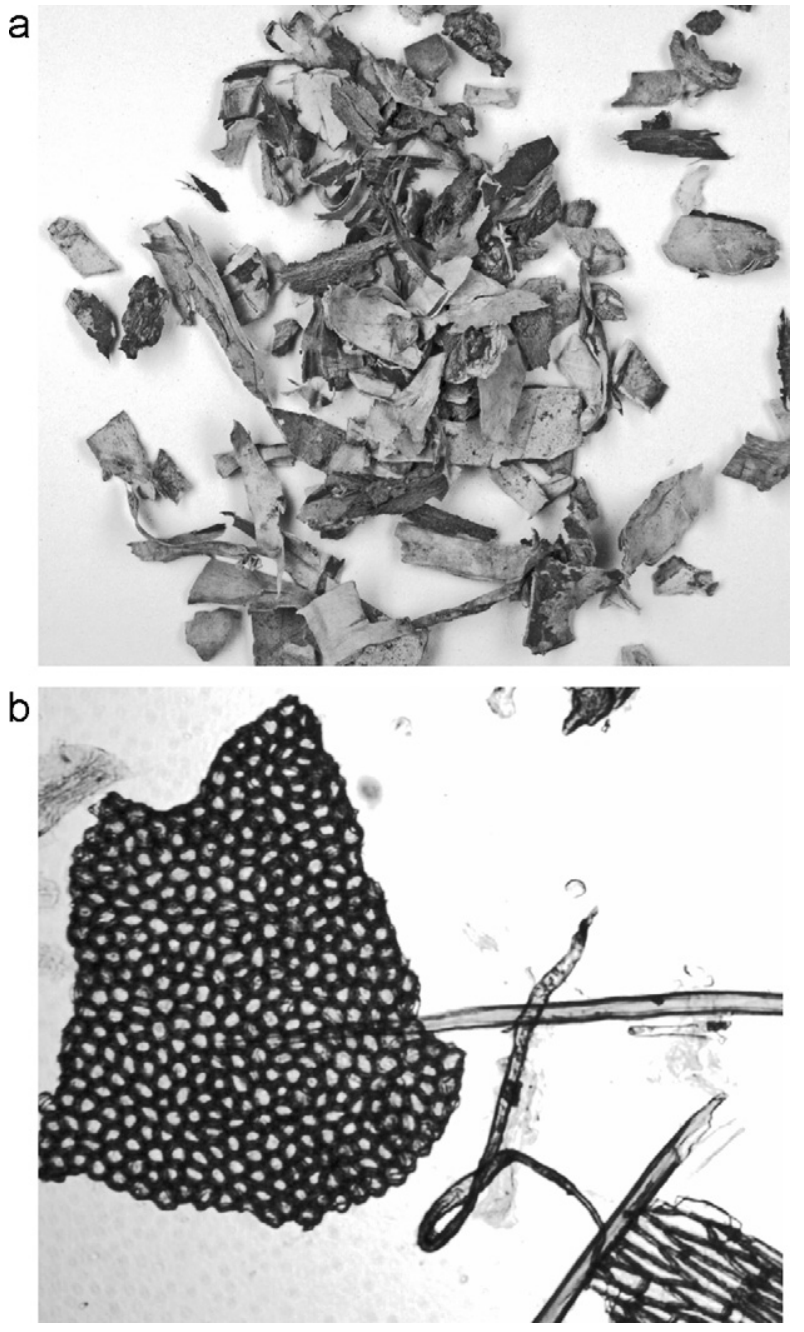

Fig. 2. Birch (Betula pendula Roth.) bark. (a) Granulometric fraction with $>2 \mathrm{~mm}$ particles, observed under the magnifying glass; (b) microscopic observations of dissociated cells obtained from the 0.180 to $0.250 \mathrm{~mm}$ granulometric fraction.

between fractions were smaller. The elongated form of the eucalypt bark fractions does not allow an easy compaction of particles.

Very little information exists on bark bulk density. Similarly to the difference found here for eucalypt and birch barks, a bulk density of $250 \mathrm{~kg} / \mathrm{m}^{3}$ was reported for $0.120-0.50 \mathrm{~mm}$ sized bark particles of E. globulus (Sarin and Pant, 2006).

It is obvious that bulk densities of granulated barks are much lower than the corresponding particle density. Birch and eucalypt barks have basic densities ranging, respectively, from $452 \mathrm{~kg} / \mathrm{m}^{3}$ to $559 \mathrm{~kg} / \mathrm{m}^{3}$ (Bhat, 1982; Lamb and Marden, 1968), and from 374 to $454 \mathrm{~kg} / \mathrm{m}^{3}$ (Quilhó and Pereira, 2001). This difference between the

Table 2

Bulk density $\left(\mathrm{kg} / \mathrm{m}^{3}\right)$ for the different granulometric fractions of the birch and eucalypt barks.

\begin{tabular}{lll}
\hline Granulometric fraction, $\mathrm{mm}$ & \multicolumn{2}{l}{ Bulk density, $\mathrm{kg} / \mathrm{m}^{3}$} \\
\cline { 2 - 3 } & Birch & Eucalypt \\
\hline$<0.180$ & 311.3 & 160.8 \\
$0.180-0.250$ & 305.1 & 155.5 \\
$0.250-0.450$ & 300.7 & 189.9 \\
$0.450-0.850$ & 271.0 & 192.1 \\
$0.850-2.00$ & 255.6 & 153.2 \\
$>2.00$ & 239.0 & 181.2 \\
Mean & $276.9 \pm 28.9$ & $169.4 \pm 18.5$ \\
\hline
\end{tabular}

Table 3

Ash content (\% of total dry mass) of the different granulometric fractions after milling of barks.

\begin{tabular}{llc}
\hline Granulometric fraction, $\mathrm{mm}$ & \multicolumn{2}{l}{ Ash, \% of total dry mass } \\
\cline { 2 - 3 } \cline { 2 - 3 } & Birch & Eucalypt \\
\hline$<0.180$ & 3.4 & 23.1 \\
$0.180-0.250$ & 4.5 & 14.7 \\
$0.250-0.450$ & 2.5 & 15.9 \\
$0.450-0.850$ & 2.6 & 7.9 \\
$0.850-2.00$ & 2.1 & 6.7 \\
$>2.00$ & 2.2 & 4.3 \\
Mean & $2.9 \pm 0.9$ & $12.1 \pm 7.1$ \\
\hline
\end{tabular}

solid density of both barks is in accordance with their corresponding structural features, as discussed previously.

\subsection{Ash content and composition}

The ash content of the birch and eucalypt bark samples collected at the mill after milling and separation into the different granulometric fractions is reported in Table 3. The whole biomass of birch and eucalypt barks had an ash content of $2.9 \%$ and $12.1 \%$, respectively, determined as a mass weighed average of all fractions.

For B. pendula bark, Werkelin et al. (2005) reported a similar ash content of 3.8\% and Saarela et al. (2005) reported values between $1.0 \%$ and $1.9 \%$. Ash content for other birch species was reported as $1.7 \%$ for Betula alleghaniensis and $1.8 \%$ for Betula papyrifera (Corder, 1976).

The birch bark fractions showed higher ash content in the finer particles $(4.5 \%$ in the $0.180-0.250 \mathrm{~mm}$ fraction and $2.2 \%$ in the $>2 \mathrm{~mm}$ fraction). It is known that ash tends to accumulate in the finer sized fraction during biomass processing due to the small size and brittleness of inorganic material (Bridgeman et al., 2007; Liu and $\mathrm{Bi}, 2011$ ). However the extent of mineral accumulation in bark fractions depends on the species (Miranda et al., 2012).

The ash content of E. globulus bark was reported as $4.7 \%$ (Vázquez et al., 2008) and 4.5\% (Akyuz et al., 2003) and in the range of 1.6-3.5\% (Pereira, 1988b). The present eucalypt bark sample had a much higher mineral content which shows that the bark obtained in the mill contained considerable contamination with soil particles and other extraneous fine material. The amount of incrustated sand granules was notorious by a direct macroscopic observation of the sample. Due to their small size, these particles were retained in the finer granulometric fractions after the milling and screening. As shown by Table 3, this occurred especially in the finest particles (e.g. $23.1 \%$ ash content in particles size below $0.180 \mathrm{~mm}$ ) while the larger dimension particles showed an ash content similar to the values reported in the literature for eucalypt bark $(4.3 \%$ in $>2 \mathrm{~mm}$ particles).

A similar occurrence of substantial accumulation of minerals was also found for pine bark obtained at the mill (Miranda et al., 2012). This clearly shows the importance of bark cleaning during field and mill handling in order to avoid unsuitable contaminations during subsequent bark valorization steps.

The occasional problem of excessive sand and soil in the eucalypt stem raw-material for the pulping industry is already identified, depending on the care taken by contractors during field tree harvesting and handling since the soft and moist eucalypt bark allows easy incrustation of the mineral particles.

Two of the bark granulometric fractions $(0.250-0.450 \mathrm{~mm}$ and $<0.180 \mathrm{~mm}$ ) were characterized in relation to mineral composition, as shown in Table 4.

The concentrations of the major elements were different in both species. Birch bark contained in relation to eucalypt bark in the $0.250-0.450 \mathrm{~mm}$ fraction more $\mathrm{N}(0.69 \%$ vs. $0.26 \%)$ and $\mathrm{P}(0.075 \%$ 
Table 4

Elemental concentrations in bark samples of birch and eucalypt determined in the $0.250-0.450 \mathrm{~mm}$ and $<0.180 \mathrm{~mm}$ granulometric fractions.

\begin{tabular}{lccllll}
\hline & \multicolumn{2}{l}{ Birch } & & \multicolumn{2}{l}{ Eucalypt } \\
\cline { 2 - 3 } \cline { 5 - 6 } \cline { 5 - 6 } & $0.250-0.450 \mathrm{~mm}$ & $<0.180 \mathrm{~mm}$ & & $0.250-0.450 \mathrm{~mm}$ & $<0.180 \mathrm{~mm}$ \\
\hline $\mathrm{N}(\%)$ & 0.69 & 0.50 & & 0.26 & 0.19 \\
$\mathrm{Ca}(\%)$ & 0.393 & 0.303 & & 0.623 & 0.181 \\
$\mathrm{Mg}(\%)$ & 0.072 & 0.049 & & 0.154 & 0.120 \\
$\mathrm{Na}(\%)$ & 0.013 & 0.011 & & 0.070 & 0.080 \\
$\mathrm{~K}(\%)$ & 0.242 & 0.169 & & 0.308 & 0.230 \\
$\mathrm{P}(\%)$ & 0.075 & 0.022 & & 0.001 & 0.001 \\
$\mathrm{Cu}(\mathrm{mg} / 1000 \mathrm{~g})$ & 3.37 & 1.86 & & 4.70 & 4.08 \\
$\mathrm{Zn}(\mathrm{mg} / 1000 \mathrm{~g})$ & 216.77 & 152.58 & & 11.39 & 6.45 \\
$\mathrm{Ni}(\mathrm{mg} / 1000 \mathrm{~g})$ & 1.77 & 1.65 & & 5.37 & 3.68 \\
$\mathrm{Cr}(\mathrm{mg} / 1000 \mathrm{~g})$ & 2.18 & 1.72 & & 9.38 & 3.01 \\
$\mathrm{~Pb}(\mathrm{mg} / 1000 \mathrm{~g})$ & 2.15 & 1.43 & & 2.02 & 1.47 \\
\hline
\end{tabular}

vs. $0.001 \%)$, but less Ca (0.39\% vs. $0.62 \%), \mathrm{K}(0.24 \%$ vs. $0.31 \%)$ and $\mathrm{Mg}$ ( $0.07 \%$ vs. $0.15 \%)$.

High concentration of $\mathrm{Zn}$ was found in the ashes of birch bark with $217 \mathrm{mg} / \mathrm{kg}$ in comparison with $11 \mathrm{mg} / \mathrm{kg}$ in eucalypt bark.

There were only small differences in the mineral composition of both fractions (Table 4) with the exception of Ca concentration which decreased substantially in the finest fraction of eucalypt bark.

The values are in the range of those reported for birch barks by Werkelin et al. (2005), Saarela et al. (2005) and Reimann et al. (2007) and for eucalypt barks by Pereira (1988b) and Damin da Silva et al. (1983).

\subsection{Alkaline extraction}

Alkaline extraction with $1 \% \mathrm{NaOH}$ solubilized $51.7 \%$ of birch bark and $43.3 \%$ of eucalypt bark. These results are in the range found recently for the alkaline extraction of spruce and pine barks (Miranda et al., 2012) but are higher than the $1 \% \mathrm{NaOH}$ extractives reported for E. globulus bark by Vázquez et al. (2008) and by Pereira (1988b), respectively, at 26.6\% and 20.4-30.6\%. Harkin and Rowe (1971) also reported for B. alleghaniensis and B. papyrifera $28.4 \%$ and $25.1 \%$, respectively.

The higher amounts of substances removed by alkaline lixiviation of birch bark in comparison to eucalypt bark are in relation with the presence of higher amounts of extractives and suberin as well as of hemicelluloses. Such compounds are present in higher contents in the birch bark, as discussed below.

\subsection{Summative chemical composition}

The birch and eucalypt barks were chemically characterized and the composition calculated as a mass weighed average of all granulometric fractions is shown in Table 5.

There are considerable differences between birch and eucalypt barks in relation to extractives, suberin and holocellulose contents. Eucalypt bark contains less extractives than birch bark but more cellulose and hemicelluloses expressed as holocellulose.

As regards the total extractives content, birch bark has approximately three times more extractives than eucalypt bark (respectively, $17.6 \%$ and 6.5\%). Polar compounds extracted by ethanol and water, which include especially phenolics and polyphenolics, corresponded to a significant proportion of the total content $(60.8 \%$ in birch and $83.0 \%$ in eucalypt of the total extractives). Waxes and other non-polar compounds that are soluble in dichloromethane and methanol make up the remaining bark extractives, representing $31.8 \%$ of the total extractives in birch bark, and $16.9 \%$ in eucalypt bark.
Table 5

Summative chemical composition (\% o.d. material) of the birch and eucalypt barks, calculated as mass weighed average of all granulometric fractions.

\begin{tabular}{lrc}
\hline & Birch & Eucalypt \\
\hline Ash & 2.9 & 12.1 \\
Extractives & 17.6 & 6.5 \\
$\quad$ Dichloromethane & 5.1 & 0.9 \\
Methanol & 0.5 & 0.2 \\
Ethanol & 5.5 & 1.3 \\
Water & 5.2 & 4.1 \\
Suberin & 5.9 & $0.98^{\mathrm{a}}$ \\
Lignin & 27.9 & 34.1 \\
Klason & 26.4 & 26.6 \\
Acid soluble & 1.5 & 7.5 \\
Holocellulose & 49.8 & 62.6 \\
\hline
\end{tabular}

a Suberin content determined in 40-60 mesh fraction.

Appreciable differences are also found in the content of suberin. The birch bark sample contained a considerable amount of suberin (5.9\%) whereas the eucalypt bark contained a very small amount (less than 1\%). This is in direct relation with the differences in the anatomical structure of both barks, i.e. with the absence of a rhytidome with suberized phellem tissues in eucalypt bark.

The birch and eucalypt bark samples showed similar cell wall lignification but there was a striking chemical difference between both barks in relation to holocellulose content: eucalypt bark had much higher holocellulose (62.6\% vs. $49.8 \%$ ).

There are few published references on the chemical composition of hardwood barks. For the birch barks of B. alleghaniensis and B. papyrifera, Harkin and Rowe (1971) reported, respectively, total extractives $17.4 \%$ and $22.4 \%$, and lignin $40.6 \%$ and $37.8 \%$.

For E. globulus bark, Yadav et al. (2002) reported 7.2\% alcohol extractives, $15.5 \%$ water extractives, $28.0 \%$ lignin and $62.2 \%$ total carbohydrates. Vázquez et al. (2008) reported $19.2 \%$ lignin and Sakai (2001) $18.6 \%$ lignin, $43.2 \%$ cellulose and $19.6 \%$ pentosans. Pereira (1988b) referred 6.3-8.5\% extractives, 16.7-21.1\% Klason lignin, $48.2-54.9 \%$ cellulose and $7.0-19.6 \%$ pentosans.

The carbohydrate composition is given by Table 6 in relation to the proportion of neutral monosaccharides. There are also considerable differences between birch and eucalypt barks especially in relation to glucose and xylose contents. Glucose represented $68.4 \%$ and $47.0 \%$ of total neutral monosaccharides, respectively, in eucalypt and birch barks and xylose $23.2 \%$ and $33.8 \%$, respectively. This is clearly indicative of a different proportion of cellulose and hemicelluloses in eucalypt and birch bark. Taking roughly the ratio of glucose to xylose as indicative of cellulose to hemicelluloses, there is a striking difference: 2.96 in eucalypt bark and 1.39 in birch bark. The chemical composition of the xylans also differs between the species: the ratio of arabinose to xylose was 0.12 in eucalypt bark and 0.31 in birch bark.

Vázquez et al. (2008) reported similar monomeric composition of polysaccharides for E. globulus bark: a predominance of glucose with $70.4 \%$ and an important content of xylose of $20.8 \%$ with $3.6 \%$ of galactose, $3.7 \%$ of arabinose and $1.4 \%$ of mannose. Bargatto (2010) reported also the carbohydrate composition of $E$. grandis $\times$ urophylla and $E$. grandis barks, respectively, for glucose

Table 6

Carbohydrate composition of the different barks in \% of total neutral monosaccharides (40-60 mesh granulometric fraction).

\begin{tabular}{lcc}
\hline Monosaccharide & Birch & Eucalypt \\
\hline Glucose & 47.0 & 68.4 \\
Mannose & 4.1 & 1.9 \\
Galactose & 3.8 & 3.3 \\
Rhamnose & 1.1 & 0.4 \\
Xylose & 33.8 & 23.2 \\
Arabinose & 10.3 & 2.7 \\
\hline
\end{tabular}


Table 7

Chemical composition (\% of total dry mass) of the different granulometric fractions after milling of birch and eucalypt barks.

\begin{tabular}{|c|c|c|c|c|c|c|}
\hline & \multicolumn{3}{|c|}{ Birch bark } & \multicolumn{3}{|c|}{ Eucalypt bark } \\
\hline & $\mathrm{F}$ & M & $\mathrm{C}$ & $\mathrm{F}$ & M & $\mathrm{C}$ \\
\hline Extractives & 24.0 & 15.6 & 12.0 & 11.0 & 6.2 & 5.5 \\
\hline Dichloromethane & 7.5 & 4.2 & 3.1 & 2.6 & 0.9 & 0.6 \\
\hline Methanol & 0.5 & 0.5 & 0.2 & 0.4 & 0.3 & 0.2 \\
\hline Ethanol & 8.8 & 5.1 & 4.3 & 1.9 & 1.2 & 1.1 \\
\hline Water & 6.3 & 5.7 & 4.4 & 6.2 & 4.0 & 3.6 \\
\hline Suberin & 7.3 & 6.0 & 7.2 & - & - & - \\
\hline Lignin & 27.1 & 28.5 & 27.1 & 29.0 & 29.2 & 22.1 \\
\hline Klason & 26.0 & 27.2 & 25.1 & 26.6 & 26.1 & 18.9 \\
\hline Acid soluble & 1.1 & 1.4 & 2.0 & 2.4 & 3.1 & 3.1 \\
\hline Holocellulose & 38.0 & 56.3 & 55.1 & 64.3 & 53.4 & 70.0 \\
\hline
\end{tabular}

Granulometric fractions: fine $(\mathrm{F},<0.180 \mathrm{~mm})$, medium $(\mathrm{M}, 0.250-0.450 \mathrm{~mm})$ and coarse $(C,>2 \mathrm{~mm})$

$76.4 \%$ and $77.6 \%$, xylose $18.9 \%$ and $16.9 \%$, galactose $1.8 \%$ and $2.3 \%$, arabinose $2.0 \%$ and $2.2 \%$, ramnose $0.6 \%$ and $0.7 \%$.

Harkin and Rowe (1971) reported for B. alleghaniensis and $B$. papyrifera, respectively: glucose $54 \%$ and $53 \%$, galactose $3 \%$ and $2 \%$, mannose $1 \%$, xylose $32 \%$ and $36 \%$, arabinose $8 \%$ and $6 \%$.

It is interesting also to notice that the chemical difference in polysaccharide composition between the B. pendula and E. globulus barks also occurs in the corresponding woods: xylose and glucose contents (\% of total neutral monosaccharides) represent, respectively, $32.6 \%$, and $61.4 \%$ in B. pendula wood and $20.0 \%$ and $75.3 \%$ in E. globulus wood (Pinto et al., 2005).

\subsection{Effect of particle size on bark chemical composition}

Table 7 summarizes the results obtained for the chemical composition of the fractions of $<0.180 \mathrm{~mm}$ (fine), $0.250-0.450 \mathrm{~mm}$ (medium) and $>2 \mathrm{~mm}$ (coarse) of the milled birch and eucalypt barks.

A particle size effect was observed on the content and composition of extractives of birch and eucalypt bark. Extractives were present preferentially in the finest fraction due to enrichment in non polar and polar compounds. The extractives content was highest in the fine fraction, i.e. $24.0 \%$ in comparison with $12.0 \%$ for the coarser fraction in the case of birch bark and $11.0 \%$ vs. $5.5 \%$ in eucalypt bark. As regards composition of extractives there was an enrichment in dichloromethane and ethanol solubles in the fine fraction especially in the case of birch bark.

For the structural components, the observed differences were either of small magnitude or without a consistent pattern of variation for birch bark. For instance, suberin content was similar in the three birch bark fractions. However, consideration of the chemical composition based on extractive-free material (as could be obtained after extraction of the bark) points out that suberin content increases in the finer fraction: respectively, $9.6 \%, 7.1 \%$ and $8.1 \%$ of extractive-free material in the fine, medium and coarse fractions.

In eucalypt bark the lignin content was highest in the fine fraction, i.e. $29.0 \%$ in comparison with $22.1 \%$ for the coarser fraction while holocellulose content was highest in the coarse fraction.

The differences in the chemical composition of the bark fractions are due to the different anatomical tissues that condition the distribution of sizes after grinding (Vázquez et al., 2001). Bridgeman et al. (2007) reported that cellulose, hemicelluloses and lignin tend to remain in the larger particle sized fraction. Tamaki and Mazza (2010) and Chundawat et al. (2007) also reported compositional changes with particle size: with increasing particle size extractives content tend to decrease and hemicelluloses and glucan content to increase while lignin content did not show clear trends.
The results showed that grinding and fractionation by particle size are unit operations that may be used to selective enrich fractions in soluble materials (the finest fractions) for both barks. Coarser fractions tend to have a higher holocellulose content and will be therefore more suitable for carbohydrate related uses.

\section{Conclusions}

Structural and anatomical features are important characteristics that influence bark processing, namely their grinding behavior and particle fractioning. Accordingly the barks of birch and eucalypt showed different size reduction pattern and particle characteristics. Therefore biomass pre-treatments such as milling and fractioning have to be adapted to the specific biomass source.

Birch and eucalypt barks substantially differed in their chemical composition, leading to different potential valorization routes.

Birch bark has a high content of extractives and an appreciable amount of suberin that allow considering their use. Fractionation by size is adequate for a selective enrichment in these components in the finer fractions.

Eucalypt bark has a high content of cellulose and hemicelluloses that is enriched in the coarser fraction. The fibrous character of this fraction shows its potential as a fiber source.

The results also showed the importance of a careful field handling of stems in order to avoid excessive contamination with minerals.

\section{Acknowledgements}

This work was supported by the EU research project "AFORE - Forest biorefineries: Added-value from chemicals and polymers by new integrated separation, fractionation and upgrading technologies" under the 7th Research Framework Programme. Centro de Estudos Florestais is a research unit supported by the national funding of FCT - Fundação para a Ciência e a Tecnologia (PEstOE/AGR/UI0239/2011).

\section{References}

Akyuz, M., Sahin, A., Alma, A., Bektap, I., Usta, A., 2003. Conversion of tree bark into bakelite-like thermosetting materials by phenolation. In: XII World Forest Congress, Québec City, Canada, September 30.

Bargatto, J., 2010. Avaliação do potencial da casca de Eucalyptus spp. para a produção de bioethanol. Ph.D. Dissertation. Universidade de S. Paulo, Escola Superior de Agricultura Luiz de Queirós, Piracicaba, Brazil.

Bhat, K.M., 1982. Anatomy, basic density and shrinkage of birch bark. IAWA Bulletin $3(3-4), 207-213$

Bridgeman, T.G., Darvell, L.I., Jones, J.M., Williams, P.T., Fahmi, R., Bridgwater, A.V., Barraclough, T., Shield, I., Yates, N., Thai, S.C., Donnison, I.S., 2007. Influence of particle size on the analytical and chemical properties of two energy crops. Fuel 86, 60-72.

CEPI, 2010. Key Statistics 2010. European Pulp and Paper Industry.

Chundawat, S.P.S., Venkatesh, B., Dale, B.E., 2007. Effect of particle size based separation of milled corn stover on AFEX pretreatment and enzymatic digestibility. Biotechnology and Bioengineering 96 (2), 219-231.

Corder, S.E., 1976. Properties and uses of bark as an energy source. Research Paper 31, Forest Research Laboratory, Oregon State University, Corvallis.

Damin da Silva, H., Poggiani, F., Coelho, L.C., 1983. Biomass, nutrient content and concentration in five Eucalyptus species cultivated on low soil fertility. Boletim de Pesquisa Florestal, Colombo 6/7, 9-25.

Demirbas, A., 2010. Biorefineries for Biomass Upgrading Facilities (Green Energy and Technology). Springer-Verlag, London.

Fengel, D., Wegener, G., 1984. Wood: Chemistry, Ultraestructure, Reactions. Walter de Gruyter, Berlin.

Harkin, J.M., Rowe, J.W., 1971. Bark and its possible uses. Research Note FPL, 091. U.S Department of Agriculture. Forest Service. Forest Products Laboratory, Madison, Wisconsin.

Jackson, M.L., 1958. Soil Chemical Analysis. Prentice-Hall, Inc., Madison, Wisconsin. Jensen, W., 1948. Om ytskiktsavfallet vid framställning avbörkfaner (About the surface layer waste from production of birch veneer). Ph.D. Thesis. Acta Acad. Aboensis, Math. Phys. XVI, 3.

Lamb, F.M., Marden, R.M., 1968. Bark specific gravities of selected Minnesota tree species. Forest Products Journal 18 (9), 76-82. 
Liu, X., Bi, X.T., 2011. Removal of inorganic constituents from pine barks and switchgrass. Fuel Processing Technology 92 (7), 1273-1279.

Marti, F., Muñoz, J., 1957. Flame Photometry. Elsevier Publishing, London.

Miranda, I., Gominho, J., Mirra, I., Pereira, H., 2012. Chemical characterization of barks from Picea abies and Pinus sylvestris after fractioning into different particle sizes. Industrial Crops and Products 36, 395-400.

Patt, R., Kordsachia, O., Fehr, J., 2006. European hardwoods versus Eucalyptus globulus as a raw material for pulping. Water Science and Technology 40, 39-48.

Pereira, H., 1988a. Chemical composition and variability of cork form Quercus suber L. Water Science and Technology 22, 211-218.

Pereira, H., 1988b. Variability in the chemical composition of plantation eucalypts (Eucalyptus globulus Labill.). Wood and Fiber Science 20 (1), 82-90.

Pereira, H., Graça, J., Rodrigues, J.C., 2003. Wood chemistry in relation to quality. In: Barnett, J.R., Jeronimidis, G. (Eds.), Wood Quality and its Biological Basis. CRC Press, Blackwell Publishing, Oxford, pp. 53-83.

Pereira, H., Miranda, I., Gominho, J., Tavares, F., Quilhó, T., Graça, J., Rodrigues, J., Shatalov, A., Knapic, S., 2010. In: Centro de Estudos Florestais (Ed.), Qualidade Tecnológica do Eucalipto Eucalyptus globulus. Instituto Superior de Agronomia, Universidade Técnica de Lisboa, Lisboa.

Pinto, P.C., Evtuguin, D.V., Pascoal Neto, C., 2005. Structure of hardwood glucuronoxylans: modifications and impact on pulp retention during wood kraft pulping. Carbohydrate Polymers 60, 489-497.

Quilhó, T., Pereira, H., Richter, H.G., 1999. Variability of bark struture in plantationgrown Eucalyptus globulus. IAWA Journal 20 (2), 171-180.

Quilhó, T., Pereira, H., Richter, H.G., 2000. Within-tree variation in phloem cell dimensions and proportions in Eucalyptus globulus. IAWA Journal 21 (1), 31-40.

Quilhó, T., Pereira, H., 2001. Within and between-tree variation of bark content and wood density of Eucalyptus globulus in commercial plantations. IAWA Journal 22 (3), 255-265.

Reimann, C., Arnoldussen, A., Finne, T.E., Koller, F., Nordgulen, Ø., Englmaier, P., 2007. Element contents in mountain birch leaves, bark and wood under different anthropogenic and geogenic conditions. Applied Geochemistry 22, 1549-1566.

Repola, J., 2008. Biomass equations for birch in Finland. Silva Fennica 42 (4), 605-624.

Rowell, R.M., 2005. Handbook of Wood Chemistry and Wood Composites. CRC Press, Madison, USA
Saarela, K.-E., Harju, L., Lill, J.-O., Heselius, S.-J., Rajander, J., Lindroos, A., 2005. Quantitative elemental analysis of dry-ashed bark and wood samples of birch, spruce and pine from south-western Finland using PIXE. Acta Academiae Aboensis, Series B 65 (4), 1-27.

Sakai, K., 2001. Chemistry of bark. In: Hon, D.N.-S., Shiraishi, N. (Eds.), Wood and Cellulosic Chemistry. , 2nd ed. Marcel Dekker, New York.

Sarin, V., Pant, K.K., 2006. Removal of chromium from industrial waste by using eucalyptus bark. Bioresource Technology 97, 15-20.

Sen, A., Miranda, I., Santos, S., Graça, J., Pereira, H., 2010. The chemical composition of cork and phloem in the rhytidome of Quercus cerris bark. Industrial Crops and Products 31, 417-422.

Silva, G.G.D., Guilbert, S., Rouau, X., 2011. Successive centrifugal grinding and sieving of wheat straw. Powder Technology 208, 266-270.

Tamaki, Y., Mazza, G., 2010. Measurement of structural carbohydrates, lignins, and micro-components of straw and shives: effects of extractives, particle size and crop species. Industrial Crops and Products 31, 534-541.

Trockenbrodt, M., 1991. Qualitative structural changes during bark development in Quercus robur, Ulmus glabra, Populus tremula and Betula pendula. IAWA Bulletin 12 (1), 5-22.

Vázquez, G., Parajó, J.C., Antorrena, G., 1987. Sugars from pine bark by enzymatic hydrolysis. Effect of sodium chlorite treatments. Water Science and Technology 21, 167-178.

Vázquez, G., González-Alvarez, J., Freire, S., López-Suevos, F., Antorrena, G., 2001. Characteristics of Pinus pinaster bark extracts obtained under various extraction conditions. Holz als Roh und Werkstoff 59, 451-456.

Vázquez, G., Fontenla, E., Santos, J., Freire, M.S., González-Álvarez, J., Antorrena, G., 2008. Antioxidant activity and phenolic content of chestnut (Castanea sativa) shell and eucalyptus (Eucalyptus globulus) bark extracts. Industrial Crops and Products 28, 279-285.

Werkelin, J., Skrifvars, B-J., Hupa, M., 2005. Ash-forming elements in four Scandinavian wood species. Part 1: Summer harvest. Biomass \& Bioenergy 29, 451-466.

Yadav, K.R., Sharma, R.K., Kothari, R.M., 2002. Bioconversion of eucalyptus bark waste into soil conditioner. Bioresource Technology 81, 163-165 (Short communication). 